\title{
ЗАБЕЗПЕЧЕННЯ ЕКОНОМІЧНИХ ПРАВ ЛЮДИНИ В УМОВАХ ПАНДЕМІї COVID-19: ДОСВІД ЗАРУБІЖНИХ КРАЇН
}

Шеховцова T. 0.

Стаття присвячена дослідженню особливостей забезпечення економічних прав людини $і$ громадянина в умовах пандемї COVID-19. Економічні права громадян є важливим складником правового статусу особи, і в умовах глобалізації набувають особливого значення, оскільки виступають мірою i засобом економічної інтеграції держави. У 2020 р. пандемія COVID-19 стала одним з найсерйозніших викликів сучасності, який завдав серйозного удару по світовій економіці. Обґрунтовано, що розширенню економічної кризи значною мірою сприяє глобалізація, яка, з одного боку, призводить до інтенсифікації економічного співробітництва між державами, його транснаціоналізацію, а з іншого сприяє загостренню ряду економічних проблем, які в умовах глобальної інтеграції виходять далеко за рамки конкретної держави. В умовах пандемії глобальні виробничі ланцюги виявились недостатньо стійкими, тому нормальна економічна діяльність держав, залежних від глобальної торгівлі, виявилась практично паралізованою. Обгрунтовано, що в умовах практично повної зупинки господарської діяльності, руйнування балансу між попитом і пропозицією, а також розривом зв'язків між виробником і споживачем активна участь держави у регулюванні економіки $і$, як наслідок, забезпеченні економічних прав громадян набуває особливого значення.

Акцентується увага на тому, що в період пандемії економіки держав стикаються з рядом проблем, серед яких основними $\epsilon$ : стагнація виробництва і експлуатації підприємств; труднощі із фінансуванням; труднощі при відновленні роботи підприємств. Попри те, що кожна держава встановлює та реалізує власні антикризові програми, їм притаманний ряд спільних рис, зокрема: поєднання заходів фінансового і нефінансового характеру; акцент на забезпечення стабільності і розвитку підприємств малого і середнього бізнесу; дотримання прав працівників, недопущення їх дискримінації; збільшення повноважень і впливу державних інститутів; стимулювання розвитку інноваційних технологій.

Ключові слова: економічні права людини, глобалізачія, пандемія COVID-19, економічна криза, глобальні виробничі ланцюги, малий і середній бізнес, фінансова допомога громадянам.
Shekhovtsova T. O. Ensuring economic human rights in a pandemic COVID-19: experience of foreign countries

The article is devoted to the study of peculiarities of ensuring economic human rights in a pandemic COVID-19. Economic rights is an important component of the legal status of person. They acquire special significance in the context of globalization, because they act as a measure and means of economic integration of the state. In 2020 pandemic COVID-19 has become one of the most serious challenges of our times, which dealt a serious blow to the global and national economy. It is substantiated that expansion of the economic crisis is greatly facilitated by globalization. On the one hand, globalization leds to intensification of economic cooperation between countries, its transnatiolization; on the other hand, it contributes to the aggravation of economic problems, which go far beyond a state in the context of global integration. Global production chains have become insufficiently stable and effective. Consequently, normal economic activity of states, especially those, which depends on global trade, proved to be practically paralysed. It is substantiated that in conditions of almost complete cessation of economic activity, destruction of the balance between supply and demand, rupture of ties between producer and consumer, active participation of the state in regulation of the economy and, as a consequence, ensuring the economic rights of citizens acquires special significance.

Emphasis is placed on that economies of states consern with problems in pandemic, such as: stagnation of production and operation of enterprices; financial problems and risks; problems with restoring the work of enterprices. Despite the fact that each state establishes and implements its own anti-crisis programms, they also have some common features, such as: combination of financial and non-financial measures; emphasis on ensuring the stability and development of small and medium enterprices; observance of workers' rights, non-discrimination; increasing the powers and influence of state institutions; stimulated the development of innovative technologies.

Key words: economic human rights; the globalization; pandemic of COVID-19; economic crisis; global production chains; small and medium business; financial assistance to citizens. 
Постановка проблеми та її актуальність. Економічні права людини $\epsilon$ важливим складником правового статусу особи. Саме економічні права забезпечують зовнішню сферу життя людини, дають їй можливість вільно існувати та перебувати у стані економічної свободи, використовуючи свої здібності, задовольняти свої потреби та інтереси [1, с. 92]. В умовах глобалізації економічні права людини набувають особливого значення, оскільки виступають мірою економічної інтеграції держави, інтенсивності міжнародного проникнення капіталу, розвитку економічних свобод і підвищення рівня життя у світі. Водночас глобалізація призводить до суттєвих змін у змісті та структурі економічних прав особи. 3 одного боку, глобалізаційні процеси спричиняють розширення суб'єктного компоненту міжнародної економічної системи (законодавче оформлення правового статусу транснаціональних корпорацій (ТНК), формування і розвиток нових відносин в економічній сфері (міжнародний факторинг). 3 іншого боку, зважаючи на амбівалентність процесу глобалізації, можна стверджувати, що він має також і негативний вплив на зазначену категорію прав.

Зокрема, як справедливо відзначає Л.Г. Удовика, глобалізація об'єктивно породжує численні негативні соціально-економічні явища, призводить до послаблення державного контролю над національною економікою, зростання ролі транснаціональних корпорацій, що своєю чергою має наслідком зростання соціальної нерівності та соціальної напруженості [2, с. 25].

Крім того, на рівень безпеки світового суспільно-економічного розвитку загалом суттєво впливають світові загрози глобального характеру, такі як тенденція до зростання кількості локальних конфліктів, у тому числі збройних, розширення міжнародного тероризму, формування впливових незаконних збройних формувань, поширення ядерних технологій, зняття обмежень з контролю за стратегічними озброєннями [3, с. 31]. Проте одним 3 найсерйозніших викликів сучасності стала пандемія коронавірусної інфекції COVID-19.

Станом на 15 лютого 2021 р. у світі було виявлено більше 108 мільйонів випадків зараження коронавірусом, 3 яких більше 2 мільйонів летальні. Найбільша кількість випадків припадає на Північну та Південну Америку (близько 48 мільйонів) [4]. Пандемія призвела не лише до загибелі людей, але й завдала серйозного удару практично по всім сферам життєдіяльності (медична, освітня, культурна, політична, міграційна та інші).
Проте головний геополітичний перелом відбувається в економіці, яка переживає обвал.

У міру поширення пандемії економіка держав переживає значний економічний спад: велика кількість індустрій у світі переходить у розряд проблемних, значних збитків зазнає бізнес (як великий, так і середній). Зупинка економічної активності у зв'язку з карантином і соціальним дистанціюванням сприяли виникненню кризи на фінансових ринках, однак адекватні обставинам заходи реагування економічної політики постраждалих держав спроможні убезпечити від більш негативних тенденцій економічного розвитку [5, с. 30]. При цьому кожна держава розробляє і реалізує власну стратегію виходу із кризи і підтримки економіки, що безпосередньо впливає на стан реалізації економічних прав людини. 3 урахуванням того, що наразі відсутні науково обґрунтовані прогнози щодо тривалості пандемії, дослідження зарубіжного досвіду застосування антикризових заходів у цій сфері набуває особливої актуальності.

Аналіз останніх досліджень та публікацій. Методологічним підґрунтям дослідження особливостей реалізації та забезпечення економічних прав в умовах пандемії COVID-19 $\epsilon$ наукові доробки вітчизняних і зарубіжних учених, які досліджували тенденції трансформації прав людини в умовах глобалізації, насамперед таких, як: І. Білас, О. Зайчук, Л. Луць, С. Максимов, Ю. Оборотов, Н. Оніщенко, О. Петришин, Л. Удовика, І. Яковюк та інші. Крім того, у нагоді стануть здобутки українських та зарубіжних вчених щодо впливу пандемії COVID-19 на міжнародні та економічні відносини, зокрема таких, як: В. Бєлов, О. Громико, В. Гулаков, О. Іванов, М. Клінов, Т. Ковальов, О. Потьомкін, С. Ребело, Д. Сасскінд, Дж. Стігліц, М. Шерешев, О. Шумілін та інших. Водночас слід зауважити, що наразі проблеми трансформації права в цілому та прав людини зокрема в умовах поширення пандемії COVID-19 $є$ малодослідженими.

Метою статті $\epsilon$ дослідження особливостей забезпечення економічних прав людини в умовах пандемії COVID-19 на прикладі зарубіжних країн (Австрія, Китай, США).

Виклад основного матеріалу. Міжнародний валютний фонд у своїй доповіді від 13 жовтня цього року прогнозує скорочення сукупного ВВП більше ніж на 4\%. Для порівняння, у доповіді від 14 квітня зазначена цифра складала $3 \%$, що $є$ найбільшим економічним обвалом з часів Великої депресії [6]. При цьому, на думку експертів організації, найбільше постраждають від наслідків 
пандемії країни з великою залежністю від глобальної торгівлі, надання послуг чи фінансових потоків; більш оптимістичні прогнози стосовно китайської економіки, яка першою відчула на собі наслідки епідемії - за прогнозом, об'єм виробництва в Китаї в цьому році перевищить відповідний показник 2019 р.

Схожий погляд на ситуацію висловлює Організація економічного співробітництва і розвитку: нова економічна криза, спричинена пандемією, виявиться більш загрозливою для міжнародної економічної системи, ніж аналогічна у 2008 р. Так, експерти організації прогнозують падіння ВВП на 4,5\% (попередня оцінка - 6\%), а сумарний збиток світової економіки від пандемії коронавірусу до кінця 2021 р. сягне 7 трильйонів доларів, що складає цифру сукупного бюджету США (4,1 трильйонів) і Китаю (3,2 трильйонів) [7]. При цьому експерти та фінансові аналітики сходяться в одному: викликана пандемією криза обіцяє бути затяжною, а іï наслідки світова економіка буде відчувати протягом тривалого часу.

Водночас вважаємо слушною думку тих дослідників, які ще до пандемії звертали увагу на скорочення зростання економіки, яке неминуче призведе до серйозної економічної кризи. Так, економічний аналітик Джессі Коломбо, який передбачив настання кризи 2008 р., заявляв, що пандемія $\epsilon$ не причиною, а лише тригером глибокої кризи, оскільки «ми уже в самому кінці циклу, і хоча коронавірус - усього лише пара додаткових ударів кулаком, але ми вже й так йшли до рецесії до того, як почули про нього» [8, с. 26]. Крім того, на нашу думку, розширенню економічної кризи значною мірою сприяє глобалізація, яка, з одного боку, призводить до інтенсифікації економічного співробітництва між державами, його транснаціоналізацію, а з іншого - сприяє загостренню ряду економічних проблем, які в умовах глобальної інтеграції виходять далеко за рамки конкретної держави.

І. Бреммер, президент i засновник компанії Eurasia Group, виокремлює три основні геополітичні тенденції, які будуть відігравати домінуючу роль у новій побудові міжнародного правопорядку: збільшення впливу націоналізму і політики під лозунгом «моя держава понад усе», геополітичній підйом Китаю, адміністративна модель якого продемонструвала більшу ефективність в умовах кризової ситуації, і деглобалізація [9, с. 29]. Остання тенденція представляє найбільший інтерес у контексті дослідження економічних прав людини.
Глобальна перебудова відносин, розпочата з початку XXI ст., сприяла зародженню нових центрів економічної сили, перерозподілу вигод, прав та обов'язків держав, а також жорсткому зіткненню і протистоянню інтересів різних держав і груп держав. Основною метою і центральною тенденцією цієї перебудови визначалось формування глобального економічного простору, в якому відбувалося б вільне переміщення ресурсів з однієї національної економіки в іншу. На виконання цього завдання економічно розвиненими країнами впродовж останніх десятиліть активно підтримувалось i заохочувалось створення ТНК, головна особливість яких полягає в створенні мереж виробництва і реалізації глобального масштабу.

3 господарської точки зору ТНК діють у різних країнах: так, виробничі потужності таких підприємств нерідко знаходяться на території країн, що розвиваються, з огляду на низький рівень виробничих витрат, а збут продукції здійснюється там, де на неї вище попит (головним чином, у розвинених країнах). Проте в умовах пандемії глобальні виробничі ланцюги виявились недостатньо стійкими і ефективними. Наочним прикладом цього $\epsilon$ ситуація в США, де компанії виявились неспроможними виготовляти в необхідному об'ємі навіть елементарні засоби індивідуального захисту (маски, гумові рукавиці), не кажучи вже про більш технологічну складну продукцію, таку як набори для тестування і апарати штучної вентиляції легень [10, с.19]. В умовах глобального карантину і закриття кордонів діяльність ТНК виявилась практично паралізованою.

Більшість дослідників (І. Бреммер, С. Ребело, Дж. Стігліц) впевнені, що матеріально-технічні проблеми, виявлені пандемією, призведуть до зворотного процесу повернення виробництва на територію країн походження і відмови від глобальних виробничих ланцюгів [9, с.29]. Власне, цей процес розпочався задовго до пандемії: так, Президент США Д. Трамп, вступаючи у торговельну війну з Китаєм, не приховував, що одним з основних завдань своєї політики вбачає повернення виробництв, особливо високотехнологічних, на територію Америки.

Проте існує інша точка зору, згідно з якою після завершення пандемії, навпаки, актуальним виявиться подальший розвиток глобалізації і міждержавних економічних зв'язків. Прихильники цього погляду наголошують на тому, що проведення заходів із підвищення готовності економіки до криз, які обов'язково будуть вживатись країнами, знизять доходність відповідних економік 
і тим самим призведуть до необхідності пошуку способів їі підвищення. На нашу думку, у подальшому часткове згортання глобальних виробничих ланцюгів і заміна їх національними все-таки матиме місце, оскільки ефективність транснаціональної системи господарювання в умовах пандемії продемонструвала вразливість і надзвичайну ризиковість. Водночас глобальні виробничі ланцюги мають можливість продовжити функціонувати в деяких видах господарської діяльності, які мають більшу стійкість у кризових періодах.

Серед інших можливих змін в забезпеченні і реалізації економічних прав людини виокремлюють: автоматизація деяких категорій посад, які традиційно не розглядались в якості ризикових; перегляд існуючих стандартів у соціальній сфері i розширення соціального партнерства; спрямування економічної політики на досягнення повної зайнятості і нового суспільного договору; прийняття більш збалансованих законів про банкрутство; закріплення у корпоративних нормах пріоритету інтересів усіх зацікавлених сторін, а не лише акціонерів; забезпечення балансу державного і приватного регулювання економіки.

Пандемія COVID-19 призвела до зростання ролі національної держави, в тому числі в економічній сфері, яка тривалий час розвивалась в руслі глобалізації. В умовах практично повної зупинки господарської діяльності, руйнування балансу між попитом і пропозицією, а також розривом зв'язків між виробником і споживачем, саме активна участь держави у регулюванні економіки i, як наслідок, забезпеченні економічних прав громадян, набуває особливого значення. Тому вважаємо за необхідне детальніше розглянути зарубіжний досвід у частині забезпечення реалізації економічних прав людини в період пандемії.

Значний інтерес у цій сфері має досвід Китаю, який першим зіткнувся з новою інфекцією і, відповідно, перший відчув на собі їі негативні наслідки. Особливо це стосується малого і середнього бізнесу, який $є$ життєво важливим для економічного і соціального розвитку КНР: так, у 2019 р. такі підприємства забезпечили в країні 80\% зайнятості у містах і 90\% нових робочих місць [8, с. 28].

Серед основних проблем, які постали перед підприємцями в період епідемії, називають:

- різке зниження кількості замовлень i, як наслідок, стагнація виробництва і експлуатації підприємства;

- труднощі із фінансуванням i фінансовий тиск, пов'язаний з трьома основними аспектами: під час протиепідемічного простою постійні видатки, такі як заробітна плата працівників, внески соціального страхування, кошти на житлове забезпечення і орендна плата за житло, не зменшились, і частина цих витрат покладається на підприємство;

- труднощі при відновленні роботи підприємства, зокрема: повернення працівників у виробничий цикл без збоїв, різноманіття процедур отримання дозволів на проведення різних видів робіт, необхідність дотримання протиепідемічних заходів [8, с. 36-37].

3 метою забезпечення реалізації економічних прав як підприємців, так і працівників, мінімізації негативного впливу наслідків пандемії на діяльність малих і середніх підприємств, а також забезпечення стабільності їх фінансово-економічного стану, урядом КНР було сформульовано комплекс заходів:

- зниження адміністративних зборів (плата за екологічні випробування, за очищення стічних вод, за реєстрацію вибору медичного призначення, за користування дорогами та ін.);

- звільнення від орендної плати (повністю або частково, на строк від 2 до 6 місяців за умови дотримання державних вимог організації роботи і відсутності або незначної кількості звільнень);

- податкові пільги - направлені здебільшого на виробництво, транспортування та імпорт матеріалів для профілактики епідемій і контролю за ними. Серед таких заходів виокремлюють: відстрочка виплати податку на строк до 3 місяців; повне повернення коштів профспілок малих і середніх підприємств; зниження ставок деяких податків і страхових внесків; відшкодування до 75\% фактичних витрат підприємств на науководослідницькі і дослідно-конструкторські роботи для профілактики і боротьби з епідемією;

- державні субсидії - покликані стимулювати рух грошових коштів малих і середніх підприємств, забезпечити відновлення і подальше стимулювання виробництва. Вони в основному сконцентровані у сфері зайнятості (близько 45\%), відновлення виробничого підприємства і укріплення інноваційного потенціалу (субсидії на науково-дослідницькі та конструкторські роботи), а також зриви зовнішньоторговельних контрактів;

- фінансово-кредитна політика (розширення кредитної підтримки підприємств, причому з боку як державних, так і приватних банків, зниження процентних ставок за кредитами, розвиток механізму швидкого реагування i побудова мережі фінансових послуг, страхування від безробіття); 
- цільова підтримка підприємств, зайнятих в забезпеченні профілактики епідемій та контролю за ними;

- інші заходи підтримки малого і середнього бізнесу для відновлення виробництва. До них відносять: призупинення оплати комунальних послуг; допомога в поверненні на роботу працівників з інших провінцій; тимчасове скасування плати за проїзд по платним дорогам; активна інформаційна підтримка; створення спеціальних груп юристів та експертів, які надають консультації і правову допомогу підприємствам, постраждалим від епідемії; підтримка державних закупівель у малих і середніх підприємств [8, с. 38-44].

Таким чином, можна зробити висновок, що своє першочергове завдання уряд Китаю вбачає в реалізації програми підтримки малих і середніх підприємств, які $\epsilon$ важливим елементом економічної системи держави і забезпечують зайнятість та економічне благополуччя громадян. Причому комплекс підтримки включає в себе як економічні (кредити, державні субсидії, податкові пільги та ін.), так і неекономічні (інформаційні, правові, політичні) заходи. На нашу думку, саме дотримання оптимального балансу між фінансовими та нефінансовими заходами впливу дозволило КНР вийти із періоду епідемії з найменшими труднощами i навіть закласти фундамент для зростання економіки у майбутньому.

Серед європейських країн з пандемією найкраще впоралась Австрія. Оперативне впровадження заходів профілактики (карантин в Австрії був офіційно оголошений 16 березня) сприяло стримуванню інфекції і дозволило уникнути серйозних жертв серед населення. Федеральний канцлер С. Курц, пояснюючи заходи боротьби з коронавірусом, відзначив: «Наш підхід у наступні місяці буде гранично зрозумілим: свобода - в міру можливості, обмеження - в міру необхідності» [11]. Сприятлива (порівняно з іншими європейськими країнами) епідеміологічна обстановка, а також послідовна і виважена економічна політика уряду здійснили позитивний вплив й на економічну ситуацію в Австрії. Так, діючий пакет фінансової допомоги громадянам складає близько 20 млрд євро. Він включає в себе відстрочки по виплаті податку на доходи фізичних осіб (до 10 млрд євро) і прямі виплати працюючим на основі короткострокових цивільно-правових договорів і самозайнятим громадянам в об'ємі 10 млрд євро. Також реалізуються заходи, які передбачають виплату допомоги по безробіттю у розмірі 450 євро впродовж трьох місяців, скорочення найнижчої ставки подо- хідного податку з 25\% до 20\% і податкові пільги для інвестицій (максимальний розмір пільг, як і в Китаї, надається компаніям, які інвестують в сфери охорони здоров'я, цифровізації та науки). Крім того, австрійський уряд реалізує додаткові заходи підтримки нефінансового характеру. Зокрема, працівники, які мають дітей віком до 14 років, можуть взяти спеціальну відпустку за сімейними обставинами до трьох тижнів з постійною виплатою заробітної плати у повному обсязі. При цьому Уряд Австрії відшкодовує роботодавцю 1/3 заробітної плати працівників, які беруть таку відпустку [11].

Заходи підтримки бізнесу в Австрії здійснюються за чотирма основними напрямами:

- надання ліквідності приватним компаніям у вигляді позик. Загальний розмір пакету заходів підтримки ліквідності складає 50 млрд євро, при цьому основна доля виділених коштів припадає на фонд допомоги найбільш постраждалим секторам економіки;

- скорочення дефіциту ліквідності, викликаного необхідністю виплати податків і соціальних внесків. Цей напрям включає в себе відстрочки з виплати податку на доходи фізичних осіб і компаній, відрахуванні соціальних внесків на строк до 3 місяців, пільги по податку на інвестиції;

- компенсація скороченого робочого часу. Передбачає компенсацію за рахунок бюджетних коштів від 80 до 90\% втрачених доходів на строк до 3 місяців, а також тимчасове скорочення робочих годин працівників зі збереженням робочих місць;

- допомога малому бізнесу. Загальний розмір виділених асигнувань складає 2 млрд євро, а виплати не повертаються і неоподатковуються. Другий етап програми, який розпочався 320 квітня 2020 р. і триватиме до середини грудня, передбачає компенсацію до 80\% втрачених доходів малих і мікропідприємств на суму до 2 тис. євро в місяць на строк до 6 місяців. При цьому загальний розмір допомоги одній компанії може досягати 15 тис. євро [11].

Крім того, додаткові заходи економічної підтримки вживають федеральні землі. Наприклад, програма Innovate4Vienna забезпечує сприяння приватним компаніям 3 оперативної реалізації проектів, направлених на виробництво продукції, необхідної для боротьби з поширенням інфекції (медичне обладнання, засоби захисту і спеціалізоване програмне забезпечення) [11].

Отже, механізм реалізації економічних прав громадян Австрії в період пандемії COVID-19 
включає в себе комплекс заходів фінансового і нефінансового характеру, спрямований на забезпечення балансу між економічними інтересами і стабільністю та епідеміологічними вимогами. Виконанню цього завдання сприяє також австрійський менталітет, який традиційно відзначається високою дисциплінованістю, готовністю чітко виконувати владні вказівки і значним рівнем довіри до чиновників та посадовців. Проаналізувавши проміжні підсумки реалізації антикризової програми, можна стверджувати, що австрійський підхід у цілому продемонстрував свою ефективність.

Підтвердженням цієї тези слугує прогноз Європейської комісії, згідно з яким за результатами 2020 р. ВВП країни очікує загальне скорочення близько 5,5\%; водночас очікуване падіння економіки буде не таким сильним, як в інших державах єврозони. До кінця 2021 р. Австрія зможе компенсувати збитки внаслідок пандемії і повністю відновитися, а зростання ВВП досягне 5\% на рік [11].

Інший підхід забезпечення економічних можливостей громадян демонструють США, де ситуація з коронавірусом з перших днів набула особливої гостроти. Так, щоденний приріст захворюваності в цій країні складає 60-70 тис. осіб, що перевищує кількість загиблих у В'єтнамській війні. Серед причин, які зумовлюють складну епідеміологічну обстановку, називають незадовільний стан системи охорони здоров'я, самовпевненість влади, яка недооцінила небезпеку нової інфекції, а також складність політичної обстановки - деякі штати відмовлялись вводити обмеження і дотримуватись епідеміологічних норм, незважаючи на вказівки федеральної влади.

Американський підхід протистояння пандемії заснований на імперативній вказівці влади “shelter-in-place” («знаходитись у безпечному місці») i дотримуватись режиму самоізоляції. У ряді штатів введений комендантський час і закриті розважальні та усі інші нежиттєво важливі підприємства. Очевидно, що масовий карантин завдав серйозного удару по економіці держави, внаслідок чого влада змушена була піти на безпрецедентні заходи економічної санації.

Американська стратегія підтримки бізнесу умовно включає в себе два основні напрями: підтримка малого і середнього бізнесу, який традиційно займає важливе місце в економіці держави, і надання допомоги значно постраждалим секторам економіки (Severely Distressed Sectors). Розглянемо детальніше заходи, які передбачає кожен напрям.
Основним нормативно-правовим актом, який регулює надання допомоги значно постраждалим секторам економіки, $є$ Закон «Про допомогу, сприяння та економічну безпеку у зв'язку з коронавіруCOM» (Coronavirus Aid, Relief and Economic Security Act, далі - Закон або (ARES Act) від 27 березня 2020 р., який встановив систему екстраординарної підтримки економіки у розмірі \$2 трлн Розділ IV зазначеного Закону присвячений економічній стабілізації і підтримці значно постраждалим секторам економіки, яким встановлюється загальний розмір такої допомоги - \$500 млрд. Відповідно до цього нормативно-правового акту до них належать три групи підприємств:

- індустріальний блок: цивільна авіація, вантажні перевезення, інші сектори, які мають критичне значення для забезпечення національної безпеки США (загальний розмір фінансування \$46 млрд);

- будь-які інші сектори бізнесу, суб'єкти підприємництва яких підпадають під кваліфіковані вимоги блоку Загальних програм;

- середній бізнес (в розумінні CARES Act бізнес, чисельність працівників якого складає не менше ніж 500 і не більше ніж 10000 осіб) [5, с. 30-31].

При цьому до підприємств будь-якої з вище перерахованих категорій висувається ряд додаткових вимог, дотримання яких $є$ обов'язковим: суб'єкт повинен бути створений, зареєстрований за законодавством США і здійснювати підприємницьку діяльність на території США (повністю або більшу частину); більша кількість робітників повинна знаходитись на території США; пов'язаність фінансових втрат підприємства з пандемією (так звані невизначені економічні умови); заявник не повинен перебувати у процедурі банкрутства; наявність «ефективного» забезпечення виконання зобов'язань з повернення кредиту; продовження діяльності компанії в рамках і масштабах, встановлених уповноваженими державно-владними структурами (для підприємств індустріального блоку). Крім того, для підприємств середнього бізнесу встановлюється обмеження у частині управління персоналом: зокрема, такі компанії можуть розраховувати на отримання кредиту за умови збереження не менше 90\% працівників або відновлення на роботі не менше 90\% працівників, які числилися у компанії станом на 1 лютого 2020 р. у випадку, якщо вони були звільнені у зв'язку зі скороченням; заборона використання зовнішнього аутсорсингу; заборона розірвання роботодавцем колективних трудових договорів на 
весь період дії кредитного договору [5, с. 31-32]. Значний інтерес, на нашу думку, викликає встановлене CARES Act спеціальне обмеження розміру компенсації для високооплачуваних посадових осіб і топ-менеджерів відповідних компаній.

Що стосується малого бізнесу, то Законом запроваджується Програма із захисту зарплати (Payback Protection Program-PPP), відповідно до якої власники малого бізнесу, підприємства якого працювали в період всього 2019 р., мають змогу отримати кредит, спрямований на найм працівників, виплату заробітних плат, оплату комунальних послуг. Розмір кредиту може складати суму, яка в 2,5 рази перевищує середньомісячний сукупний розмір видатків на оплату праці (payroll cost) за 2019 р., але не може бути більше 10 млн доларів. При цьому поняття «видатки на оплату праці» трактується законодавцем досить широко і включає в себе: сумарні видатки на оплату праці, суми виплат по комісіям та іншим компенсаціям; суми виплат готівковими коштами; суми виплат на відпустки, батьківських, лікарняних, допомоги у зв'язку зі звільненням; суми виплат групових медичних допомог, включаючи страхові внески; суми виплат допомог у зв'язку з виходом на пенсію; місцеві і державні податкові виплати в порядку компенсації; суми платежів будь-якому незалежному підряднику, розмір яких не перевищує $\$ 100$ тис. [12, с. 33].

Серед інших заходів економічної підтримки, передбачених Законом, виокремлюються:

а) часткове списання заборгованості по кредиту у розмірі сумарних видатків на оплату праці, комунальних послуг і суми виплат на відсотки по іпотечним кредитам за період 8 тижнів;

б) «кредит на утримання працівників» (employee retention credit) - податковий кредит, передбачений для роботодавців, які закрили підприємства, або суттєво скоротили їх діяльність чи втратили не менше половини валової виручки в першому кварталі 2020 р. Розмір складає 50\% заробітної плати, яка виплачується працівникам, за максимальної виплати 5000 доларів на одного працівника [12, с. 33-34].

Крім того, у серпні 2020 р. Президент США Д. Трамп підписав низку документів, спрямованих на пом'якшення негативних економічних наслідків пандемії для громадян. Зокрема, передбачається відстрочка виплат податків на зарплату до кінця року для американців, заробітна плата яких менше $\$ 100$ тис. на рік; продовження виплат додаткової допомоги по безробіттю у розмірі $\$ 400$ на тиждень; продовження «мораторію на виселення» 3 найманого житла за невиплату оренди; відстрочка по виплатам студентських кредитів і списання процентів за ними [13]. Однак через політичні причини зазначені ініціативи не знайшли підтримки у палаті представників Конгресу США, внаслідок чого їх реалізація була відкладена.

Зважаючи на викладене, можна стверджувати, що американський законодавець використав складну, багатоступінчату систему ідентифікації і відбору суб'єктів надання фінансової допомоги з детальною регламентацією кваліфікованих ознак і диверсифікацією можливих заходів впливу. При цьому у кризовий період розширюється компетенція і можливості контролюючих органів з метою забезпечення належного використання наданих коштів.

Висновки. Отже, економічні права громадян $\epsilon$ важливим складником правового статусу особи i в умовах глобалізації набувають особливого значення, оскільки виступають мірою і засобом економічної інтеграції держави. Пандемія COVID19 стала серйозним геополітичним викликом, який призвів до небувалого обвалу світової економіки. Глобалізація сприяла розширенню економічної кризи, оскільки в умовах глобальної інтеграції існуючі проблеми вийшли далеко за рамки національної держави i набули міжнародного характеру. Тому однією з провідних тенденцій нового світового порядку після завершення пандемії може стати деглобалізація, тобто відмова від глобальних виробничих ланцюгів і зворотнє повернення виробництв у країни походження.

В умовах поглиблення економічної кризи i рецесії національні держави розробляють і реалізують власні стратегії виходу із кризи i підтримки економіки. Проаналізувавши антикризові програми Китаю, Австрії і США, можна стверджувати, що їм притаманний ряд спільних рис, зокрема: комплексність, поєднання заходів фінансового і нефінансового характеру; акцент на забезпечення стабільності і розвитку підприємств малого і середнього бізнесу; дотримання прав працівників, забезпечення їм належних і безпечних умов праці, недопущення їх дискримінації; збільшення повноважень і впливу державних інститутів, наділення ї контрольними функціями; стимулювання розвитку інноваційних технологій. Водночас політичні, економічні, правові, ментальні відмінності відповідних країн зумовлюють різноманіття спектру конкретних заходів підтримки і забезпечення реалізації економічних можливостей громадян. 


\section{Література}

1. Ковальський О.В. Економічні права людини як прояв взаємовпливу права та економіки. Актуальні проблеми держави і права. 2014. № . С. 90-97.

2. Удовика Л.Г. Глобалізаційні трансформації прав людини. Український часопис міжнародного права. Спецвипуск: Права людини. 2013. С. 22-26.

3. Білас І.Г. Сучасні виклики та загрози світовому співтовариству і проблеми забезпечення реалізації прав людини в умовах глобалізації. Український часопис міжнародного права. Спецвипуск: Права людини. 2013. С. 30-34.

4. WHO Coronavirus Disease (COVID-19) Dashboard. URL: https://covid19.who.int (дата звернення: 03.02.2021).

5. Ковалева T.K. Пандемия COVID-19 и значительно пострадавшие секторы экономики: механизмы поддержки в США. Финансовые рынки и банки. 2020. № 3. С. 30-34.

6. Долгое, неравномерное и неопределенное восхождение. URL: https://www.imf.org/ru/ News/Articles/2020/10/13/blog-a-long-uneven-anduncertain-ascent (дата обращения: 15.10.2020).

7. OECD Economic Outlook, Interim Report. URL: https: / / read.oecd-ilibrary.org/economics/oecdeconomic-outlook/volume-2020/issue-1_34ffc900-en (дата звернення: 15.10.2020).

8. Симэн Е., Шерешева М.Ю. Государственная политика КНР в отношении китайских малых и сред- них предприятий в условиях пандемии COVID-19. Государственное управление. Электронный вестник. 2020. № 79. С. 25-50.

9. Как изменится мир после COVID-19. URL: https: / / www.imf.org/external/russian/pubs/ft / fandd/2020/06/pdf/how-will-the-world-be-differentafter-COVID-19.pdf (дата обращения: 15.10.2020).

10. Стиглиц Дж. Преодоление великого разрыва. Финансы и развитие. 2020. № 4. С. 17-19. https: / /www.imf.org/external/russian/pubs/ft / fandd/2020/09/pdf/COVID19-and-global-inequalityjoseph-stiglitz.pdf.

11. Опыт Австрии в борьбе с COVID-19. URL: https://ach.gov.ru/upload/pdf/Страновой\%20обзор_ Австрия_рус.pdf (дата обращения: 25.10.2020).

12. Ковалева T.K. Пандемия COVID-19 и поддержка малого бизнеса в США: институциональные аспекты, инструменты и механизмы. Финансовые рынки и банки. 2020. № 2. С. 32-35.

13. Успеть до выборов: сможет ли Трамп реализовать новые меры по борьбе с последствиями пандемии. URL: https://russian.rt.com/world/ article/772179-ssha-tramp-koronavirus-demokraty (дата обращения: 28.10.2020).

Шеховцова Т. О., аспірант кафедри історії та теорії держави та права Запорізького національного університету 